\title{
An Assessment of Teachers' Performance Management System: The Case of Saudi Ministry of Education
}

\author{
Nada Alshaikhi ${ }^{1}, \&$ Turky Alshaikhi ${ }^{1}$ \\ ${ }^{1}$ Swansea University, United Kingdom \\ Correspondence: Nada Alshaikhi, Swansea University, United Kingdom.
}

Received: December 21, 2020

Accepted: January 20, 2021

Online Published: January 22, 2021

doi:10.5539/ibr.v14n2p102

URL: https://doi.org/10.5539/ibr.v14n2p102

\begin{abstract}
The main aim of this study is to examine the effectiveness of performance management system of teachers in the Saudi Ministry of Education.The study also explores whether the performance management system provides all the information needed to reflect teachers' efficiency and productivity. The current research aims to identify the shortcomings of the performance management system for teachers in order to determine how teaching quality may be developed and improved. This is accomplished through a self-administered questionnaire survey of teachers, designed to measure teachers' opinions of the performance management system. A total number of teachers completed the survey was 502. Statistical Package for Social Science (SPSS) was used to analysis the data. The findings of the study demonstrate that teachers' perceptions regarding their performance management system are generally oriented towards dissatisfaction. The results show that this dissatisfaction arises from the problems relating to the performance management process itself. Additionally, the performance management system for Saudi teachers does not capture the necessary information for managers to make informed decisions and policies in relation to the teachers. Moreover, many performance management system-related problems such lack of training of head teachers for conducting performance management system along with teachers' beliefs about bias errors existing in performance management system caused teachers' dissatisfaction. Therefore, this study has proposed recommendations to overcome the shortcomings of the existing system and to enhance teachers' satisfaction with their performance management system.
\end{abstract}

Keywords: performance management, performance appraisal, ministry of education

\section{Introduction}

Educational institutions, including schools around the world, face major challenges in providing quality education (Darling-Hammond et al., 2009). Teachers' performance is therefore considered an important factor that demands much attention. Teachers play significant, valuable roles in educating the youth in society. Teachers are also responsible for imparting knowledge to children during the formative years of the children's development, and teachers have an extraordinary influence on shaping the minds of future adult members of society. According to the Organisation for Economic Cooperation and Development (OECD, 2005): "Teacher quality is the single most important school variable influencing student achievement" (p. 26). The teaching profession is highly important; hence, educational development programs should be designed to enable teachers to work comfortably (i.e., with more freedom, authority and respect). One of the most crucial factors that may improve teachers' performance is an effective performance management system, as this system is capable of influencing teachers' behaviour and improving school performance. It also enhances the quality of education and may enable teachers to improve their potential. Such claims are supported by Machingambi (2013, p. 218):

A popular justification for focusing on the management of the performance and professional development of teachers is that teaching quality is regarded as the largest in-school factor that affects student learning. Therefore, managing teachers' performance is critical as it helps them continuously improve their skills, which in turn impact positively on student achievements.

Tomlinson (2000) views performance management as a tool that helps the continuous improvement of teachers' performance, along with the development of competence and realisation of potential, noting that performance management is about setting expectations and plans and helping teachers to work as professionals. Gentle (2001) argues that performance management should permeate the school environment on a daily basis and should not be seen as a simple one-off event of filing out an annual performance form. Furthermore, Gentle (2001) added that 
performance management should be used to help individuals understand what their organisation is trying to achieve and how this can be accomplished. Performance management is a means of managing individuals to ensure that organisational objectives are met through appropriate tasks, so in schools performance management can be described as a mechanism to improve and develop teaching and learning. A well-designed teacher performance management system enables school management to evaluate teachers' performance, identify and encourage good performance, recognise areas for development and improve teachers' overall performance (Tomlinson, 2000).

This study attempts to fill the gaps in the literature about performance management system in the context of the Saudi Ministry of Education, in order to develop the Saudi educational system in general and teachers' performance in particular. Further, the study aims to evaluate the effectiveness of the current perormance management system in reflecting the actual performance of Saudi teachers. Based on this, the study explores whether the performance management system provides all the information needed to reflect teachers' efficiency and productivity. In addition, the study analyses the ability of management departments within the Saudi Ministry of Education to make administrative decisions based on performance management outcomes that may affect teachers' careers, and it examines the HR polices that are based on performance management results. The current research aims to identify the shortcomings of the performance management system for teachers in order to determine how teaching quality may be developed and improved. Finally, the study aims to suggest an enhanced system for conducting an effective and efficient performance management system.

The study attempts to answer the following research questions:

RQ.1: To what extent does the current teachers' PMS in the Ministry of Education achieve its objectives?

RQ.2: Does the PMS capture the necessary information for management to make informed decisions and policies about the teachers?

RQ.3: What challenges and problems related to the PMS do Saudi teachers face?

\section{Literature Review}

Although educational organisations are different from other organisations in terms of their activities, the management structures do not differ much. Thus, educational institutions face the same administrative issues as other organisations, including the issues related to performance management systems; therefore, most educational planners and policymakers have made performance management of teachers a tool for their professional development in order to raise the quality of education. A performance management system is capable of influencing teachers' behaviour and improving school performance. It also enhances the quality of education, which, in turn, has a positive impact on student achievement (Machingambi, 2013). Teachers play significant, valuable role in improving the quality of education. Therefore, teachers should be well-monitored, and it must be ensured that they are well-trained so that they can deliver high-quality education. Thus, performance management systems are used by many governments and education leaderships all over the world to achieve this goal (Machingambi, 2013). According to Santiago et al. (2009); the major aims of performance managemnt include assessing teachers' performance, increasing the overall performance of the school, improving teachers' work-related potential as well as motivating teachers through professional development, recognition and rewards.

According to Armstrong (2014) an effective performance management system should comprise several stages. Firstly, indiviauals should know what is expected of them before they start their job, it is important to recognise that evaluation characteristics should be developed from the organisation's vision and matched with its goals, and the performance management system should provide feedback for indiviauals and identify their strengths and weaknesses. Performance management should include observing and monitoring employees' performance during the evaluation period, the collected information about employees' performance should be recorded by appraiser in order to use this information to measure actual employees' performance. The results of performance appraisal could also help with administrative decisions related to the employee as well as selections, pay increases, training and development, promotions and transfers.

According to Bartol and Martin (1998) performance appraisal results can be either positive or negative. In the case of positive results, management should promote the employee, increase their salary, offer financial and non-financial rewards, or a mixture of these. In the case of unsatisfactory performance appraisal results, management should take corrective action immediately, such as a systematic correction and development support to provide assistance for poorly-performing employees. Corrective measures include training, retraining, designing a performance improvement plan, re-setting clear performance standards and providing appropriate 
facilities in the work environment.

Performance management relies on the principle of management by agreement or participatory management rather than management by leadership (Bezuidenhout, 2000). Organisations use a performance management system as an important strategy for helping to manage the talents of their staff. This is particularly the case in organisations in the educational sector. Under the performance management system, school leaders and teachers work together in setting performance goals, reviewing performance, providing feedback and taking corrective actions. They also place emphasis on developing and starting self-managed learning plans, thus integrating individual and organisational goals (Robert, 2003; Aguinis, 2015).

In the school context, the aim of a performance management system is to identify the specific needs of teachers, provide support for continuous growth, enhance accountability, monitor the overall effectiveness of the school and appraise the performance of teachers (Santiago et al. 2009).

Literature on teacher performance (Gentle, 2001; Brower, 2005) shows that when teachers and school management work together in performance management processes for career growth in school improvement efforts, both teachers and school management tend to improve.

In this way, performance management is useful for teachers as it helps provide feedback for them, identify their strengths and weaknesses and improve their skills by identifying their development and training needs in order to improve the quality of teaching and learning (Shultz, 2006; Roberson\& Stewart, 2006). According to Verspoor (2004); Fryer et al, (2009) the success of the performance management system depends on certain factors. These include the way the system is communicated to teachers and schools, the level of teachers' training, the awareness of the performance management system that teachers receive from heads of schools, the availability of resources in schools and whether or not departments hold workshops on the performance management system. The presence of such factors helps teachers understand the procedures and processes of the performance system.

Despite the perceived benefits, the implementation of performance management in education systems is controversial. For example, performance management started in business and industry sectors where performance can be linked to payment, some researchers and practitioners in the field of education believe such a linkage is not suitable for the education environment. According to Murnane and Cohen (1986) linking performance to payment is infeasible in this environment because it is not easy to monitor teacher performance. Teachers often work as teams; therefore, linking their performance to payment could affect the teachers' cooperation. Additionally, teaching has multidimensional objectives, and it is very difficult to identify individual contributions to some of these objectives - for example, the realization of student potential.

Marsden (2000) study titled "New Economics of Performance" illustrated the effects of pay-related performance on employee motivation and relationships in public service workplaces in the United Kingdom. The study found that restraints exist regarding the use of these incentives, especially in public organisations. When the management attempts to motivate employees to improve their performance on a large scale, this action can affect the fairness of the performance management process. Additionally, such attempts may affect employees who work hard but fail to receive a fair reward. Another study conducted by Dolton et al. (2003) supports the Marsden et al. study, showing that most employees believe a pay-related performance system creates jealousy and undermines employee morale. However, in some countries where teacher performance is linked to the payment system, the difficulties related to performance management have been eliminated and the desired performance results have been achieved. Empirical studies in other countries have proven that linking teacher performance to the payment system can have a positive impact on education outcomes-for example, in England (Atkinson et al., 2009), in India (Duflo et al., 2012; Kingdon \& Teal, 2007; Muralidharan \& Sundararaman, 2009), and with the school/group PRP programmes in Kenya (Glewwe et al., 2010). Therefore, performance-related payment is an essential component of the performance management process and excluding it may render performance management system ineffective.

Heystek et al. (2005) stated that the time factor is critical in performance management as the basic work of teachers in schools is teaching students. Given the time and activities needed to carry out performance management, teachers barely have enough time to participate in the evaluation process.

As one of the most crucial parts of performance management is the evaluation stage, dissatisfaction with evaluations may lead to a decline in motivation and a sense of injustice. The lack of accurate results from the evaluation process make it difficult to link performance to administrative decisions such as promotions, rewards, training and development (Lawler, 1967). The absence of essential elements of evaluations may lead to resistance by teachers to such systems (Sergiovan \& Starrat, 1993). Appraisal systems are designed in order to motivate employees and direct their efforts towards achieving goals. If they are not accurate, there will be no 
satisfaction on the part of the staff, who will not support their implementation; therefore, they will not succeed in the end (Bartol and Martin, 1998). Robins (2007) stated that in measuring performance, evaluators should know that they are trying to evaluate invisible and subjective aspects, a process that needs special attention, particularly in the school context. However, when teacher performance management system is applied as it should be, and the difficulties related to performance management are eliminated, the desired performance results can be achieved.

\section{Theoretical Perspective}

For the purposes of this research, three theories have been selected in order to explore their applicability to performance management: goal-setting theory, expectancy theory and procedural justice theory.

\subsection{Goal-setting Theory (Latham and Locke, 1979)}

The influence of goal-setting on employees' performance has been widely studied and found to be useful due to its positive impacts on employees' performance in different work situations (Locke et al., 1984). Locke and Latham (2002) found that the difficulty and specificity of goals have a great influence on employees' performance as difficult and specific goals improve employees' performance compared to inscrutable and mysterious ones. Goal-setting theory discusses certain mechanisms that link specific and difficult goals to employees' performance results. Goals lead to a focus on priorities and motivate the efforts of individuals. Difficult and specific goals lead to continuous employees' performance of tasks. Such goals challenge people to use their knowledge and talents to increase their chances of success. The literature review indicates that there is a positive relationship between setting clear, measurable goals and employees' performance. More than $90 \%$ of experimental studies have shown the positive impact of goal-setting on employee performance (Locke \& Latham, 1990). The reason that setting goals has a positive impact on employees' performance is that the goals that are set affect the levels of effort and persistence. Furthermore, they increase a person's focus on what is to be achieved so that tasks are less likely to be put off until later (Latham et al., 2008).

\subsection{Expectancy Theory (Vroom, 1964)}

Expectancy theory is a theory of motivation first suggested by Victor Vroom in 1964. In the study of organisational behaviour, expectancy theory states that people usually have different sets of goals and can be motivated if they have certain expectations. This theory revolves around choice and explains the processes by which an individual subject makes choices. According to Vroom, motivation should be equal to the amount of effort expended in specific task situations. Choices are based on two phases of expectation (effort leads to performance, and performance leads to a specific outcome/reward). First, motivation is influenced by people's expectations and the level of effort that will achieve the intended performance goal. Motivation is also affected by the employee's perceived opportunities to obtain different results by achieving the performance goal. Individuals are motivated to the extent that they appreciate the results (i.e., rewards) obtained. According to Lehman and Geller (2004) states that reward for performance enhances the effort of individuals and thus improves performance. Expectancy theory is generally supported by empirical evidence (Tien, 2000; Vansteenkiste et al., 2005), and it is one of the most commonly used theories of motivation in the workplace.

\subsection{Procedural Justice Theory (Thibaut and Walker, 1975)}

The theory of procedural justice focuses on the perceived fairness of the procedures used in making decisions regarding the distribution of results. These procedural decisions relate to how to assess performance levels, how to address grievances and disagreements, as well as how to distribute results to employees. In the theory of procedural justice, individuals' perceptions are essential as their reactions to procedures depend on how they perceive these procedures rather than what these procedures actually are (George \& Jones, 1999). This theory suggests that individuals will be more motivated to perform when the procedures used to make decisions on the distribution of rewards are fair and when their performance evaluation is accurate. If their performance is not accurately assessed due to personal feelings that affect the evaluation or because the evaluator is not well-versed regarding the employee's contribution to the work, the motivation will, consequently, be reduced, as will individuals' performance. This theory seeks to discover the reasons why individuals view procedures as fair or unfair and the consequences of these perceptions.

The three main theories of goal-setting, expectancy and procedural justice underlie the concept of the performance management system. These three theories are strongly related to motivational aspects of the individual, which, in turn, are related to perceived increases in individuals' performance management satisfaction and, finally, the effectiveness of the performance management process. 


\section{Methodology}

This research follows a quantitative approach to achieve the research aims. This is achieved by measuring participants' perceptions of the identified research questions. Primary data was collected using a questionnaire, the study explores participants' opinions and evaluates the perceptions of Saudi public schoolteachers in relation to performance management system issues. This makes it possible to achieve the aims and objectives of the study. Thus, a questionnaire was developed to gather primary data related to the topic. The five-point Likert scale was used to check the respondents' beliefs and opinions about their acceptance of and satisfaction with the performance management system. Statistical methods were used to analyse the collected data. This study was carried out using data from male and female teachers from all Saudi regions. In this study, the target population was quite large, consisting of all the teachers in Saudi Arabian public schools in all districts. The number of Saudi teachers, both male and female, account for 518,726. Although there are no clear guidelines regarding the exact sample size, some studies (e.g. Comrey \& Lee, 1992; Tabachnick \& Fidell, 2001) have indicated that a size of 1,000 is supposed to be excellent, 500 is very good, and 300 is comfortable. Taking into consideration this advice, 502 responses were collected, considered a good sample size for effective data analysis. In this study, a web-based survey was used to collect data due to the ease of reaching the largest number of teachers, the survey was sent to various groups of Saudi teachers via email and social media, such as WhatsApp, Facebook Twitter. The quantitative research method is used to shed light on the nature of the performance management system practices existing in the Saudi Ministry of Education and their effectiveness. In particular, the quantitative research approach facilitates the investigation into and measurement of teachers' views on the performance management system process and the extent to which the process influences teachers' job satisfaction.

\section{Data Analysis Procedure}

Version 22.0 of the Statistical Package for Social Sciences (SPSS) was employed to analyse the quantitative data obtained from the survey questionnaire. According to Zikmund (2003), a vast number of researchers use statistical packages for various academic purposes, including in social science and business studies. In this study, a variety of statistical techniques were utilised for the primary data collected through the questionnaires. The statistical techniques involved both descriptive and analytical methods. After coding, the raw data were entered into SPSS, which enabled the data to be presented in statistical tables so as to help the reader observe the pattern of the analysed data. After cleaning and checking the data, it was appropriate to conduct a descriptive analysis to get a better understanding of the sample. SPSS was preformed to carry out the descriptive analysis to examine percentages, mean values and standard deviations.

\section{Results}

This section provides an analysis of the quantitative data collected from teachers working for the Saudi Ministry of Education and linked with the literature according to the following categories: perception of current performance management process, the currant HR decisions related to performance appraisal results for teachers and problems causing teachers' dissatisfaction of performance management system.

\subsection{The Currant State of Performance Management}

The first section of the questionnaire aims to investigate the stages of the current performance management system process for Saudi teachers according to the participants' perceptions. To examine this process, the three components that are analysed in this section are as follows:

\subsubsection{Strategic Planing and Goal Setting}

The statements were meant to provide an overview about the strategic planning and goal setting in Saudi Ministry of Education for Saudi public schools, see table1.1 for detailed information about the responses. The results indicate that most respondents had similar opinions about the statements in the questionnaire which suggested their level of dissatisfaction with the strategic planing and goal setting. 
Table 1-1. the responses of Likert-item scale for the strategic planning and goal setting stage

\begin{tabular}{|c|c|c|c|c|c|c|c|}
\hline \multirow[t]{2}{*}{ Questions Items } & \multirow[t]{2}{*}{ Mean } & \multirow[t]{2}{*}{ SD } & \multicolumn{5}{|c|}{ Percentage } \\
\hline & & & 1 & 2 & 3 & 4 & 5 \\
\hline $\begin{array}{l}\text { Vision and mission statement are clear, and direct teachers to } \\
\text { achieve Ministry's strategic objectives. }\end{array}$ & 2.41 & 1.29 & 30.3 & 30.9 & 14.7 & 15.3 & 8.8 \\
\hline Teachers are involved in goals and objectives setting. & 2.36 & 1.28 & 31.1 & 32.5 & 14.7 & 12.7 & 9.0 \\
\hline $\begin{array}{l}\text { Teachers are involved during the development of performance } \\
\text { management system. }\end{array}$ & 2.23 & 1.15 & 30.1 & 39.4 & 12.7 & 12.7 & 5.0 \\
\hline $\begin{array}{l}\text { Performance management system gives teachers clear way to } \\
\text { achieve Ministry's strategic objectives }\end{array}$ & 2.29 & 1.30 & 36.1 & 28.7 & 14.5 & 12.0 & 8.8 \\
\hline $\begin{array}{l}\text { Teachers consider performance objectives clear, specific and } \\
\text { measurable }\end{array}$ & 2.44 & 1.22 & 25.3 & 35.7 & 15.9 & 16.3 & 6.8 \\
\hline $\begin{array}{l}\text { Relevant performance expectations are set between teachers } \\
\text { and head teachers }\end{array}$ & 2.51 & 1.28 & 25.1 & 35.3 & 12.5 & 18.1 & 9.0 \\
\hline
\end{tabular}

\subsubsection{On-going Feedback}

This section focusses on the perceptions of teachers on on-going feedback that should be giving during the evaluation period. For this reason, teachers were requested to rate three statements, in order to examine the on-going feedback stage as shown in table 1.2. The results indicate that most respondents had similar opinions about the statements in the questionnaire which suggested their level of dissatisfaction with the on-going feedback.

Table 1-2. the responses of Likert-item scale for on-going feedback stage

\begin{tabular}{|c|c|c|c|c|c|c|c|}
\hline \multirow[t]{2}{*}{ Questions Items } & \multirow[t]{2}{*}{ Mean } & \multirow[t]{2}{*}{ SD } & \multicolumn{5}{|c|}{ Percentage } \\
\hline & & & 1 & 2 & 3 & 4 & 5 \\
\hline $\begin{array}{l}\text { Feedback is given on a periodic basis to help teachers work } \\
\text { upon improving performance. }\end{array}$ & 2.33 & 1.22 & 28.7 & 38.2 & 11.8 & 14.3 & 7.0 \\
\hline The head teacher's feedback is honest and constructive & 2.28 & 1.15 & 28.7 & 36.5 & 18.3 & 11.2 & 5.4 \\
\hline $\begin{array}{l}\text { Head teachers clearly identify teachers' weaknesses in order } \\
\text { to improve their performance. }\end{array}$ & 2.50 & 1.27 & 25.5 & 33.9 & 14.5 & 17.3 & 8.8 \\
\hline
\end{tabular}

\subsubsection{Performance Appraisal Process}

Table 1-3. the responses of Likert-item scale for the performance appraisal stage

\begin{tabular}{|c|c|c|c|c|c|c|c|}
\hline \multirow{2}{*}{ Questions Items } & \multirow{2}{*}{ Mean } & \multirow{2}{*}{ SD } & \multicolumn{5}{|c|}{ Percentage } \\
\hline & & & 1 & 2 & 3 & 4 & 5 \\
\hline $\begin{array}{l}\text { Head teachers usually meet teachers in order to clarify } \\
\text { weaknesses and strengths in their performance }\end{array}$ & 2.05 & 1.12 & 42.0 & 26.7 & 19.1 & 8.8 & 3.4 \\
\hline $\begin{array}{l}\text { Teachers clearly understand how their performance is } \\
\text { measured }\end{array}$ & 2.57 & 1.28 & 20.7 & 38.8 & 14.9 & 13.3 & 12.2 \\
\hline $\begin{array}{l}\text { The assessment of performance follows a clear, balanced and } \\
\text { fair procedure }\end{array}$ & 2.29 & 1.12 & 26.7 & 38.4 & 18.1 & 12.4 & 4.4 \\
\hline $\begin{array}{l}\text { Performance is measured against the factors previously agreed } \\
\text { upon. }\end{array}$ & 2.45 & 1.23 & 26.1 & 34.1 & 14.1 & 19.7 & 6.0 \\
\hline Performance appraisal is conducted more than once a year & 1.79 & .941 & 44.4 & 40.8 & 8.6 & 3.2 & 3.0 \\
\hline $\begin{array}{l}\text { The evaluation tool for Saudi teachers contains clear and } \\
\text { well-defined criteria }\end{array}$ & 2.49 & 1.36 & 29.1 & 31.9 & 13.1 & 12.9 & 12.9 \\
\hline $\begin{array}{l}\text { Head teachers are not well prepared and trained to conduct the } \\
\text { PA process }\end{array}$ & 2.19 & 1.21 & 35.3 & 35.5 & 11.6 & 11.4 & 6.4 \\
\hline
\end{tabular}


In order to investigate the respondents' preceptions towards the presence of a set of issues related to performance appraisal stage. When the teachers were asked whether they agreed or disagreed with the below statements regarding their perceptions of performance appraisal process, the summary of responses among teachers is shown in Table 1.3. The results indicate that most respondents had similar opinions about the statements in the questionnaire which suggested their level of dissatisfaction with the performance appraisal procss.

\subsection{The Currant HR Decisions Related to PA Results for Teachers}

This section aimed to examine the overall results of HR decisions (rewards and recognition decisions, improvement and development decisions, , terminations and transfer decisions) as shown in Table 1.4. When the teachers were asked whether they agreed or disagreed with the above statements regarding their perceptions of performance appraisal process. The results indicate that most respondents had similar opinions about the statements in the questionnaire which suggested their level of dissatisfaction with the HR dececions.

Table 1-4. the responses of Likert-item scale for the current HR decisions

\begin{tabular}{|c|c|c|c|c|c|c|c|}
\hline \multirow[t]{2}{*}{ Questions Items } & \multirow[t]{2}{*}{ Mean } & \multirow[t]{2}{*}{ SD } & \multicolumn{5}{|c|}{ Percentage } \\
\hline & & & 1 & 2 & 3 & 4 & 5 \\
\hline $\begin{array}{l}\text { Performance management system establishes a clear } \\
\text { connection between performance and reward. }\end{array}$ & 2.36 & 1.29 & 31.2 & 32.6 & 13.9 & 12.7 & 9.3 \\
\hline $\begin{array}{l}\text { The Ministry effectively provides adequate development } \\
\text { opportunities for teachers }\end{array}$ & 2.23 & 1.16 & 30.0 & 39.6 & 12.1 & 13.1 & 5.0 \\
\hline $\begin{array}{l}\text { Management takes corrective measures such as } \\
\text { systematic remedial or development support to help } \\
\text { underperforming teachers. }\end{array}$ & 2.33 & 1.33 & 36.8 & 29.0 & 12.7 & 11.9 & 9.1 \\
\hline $\begin{array}{l}\text { Unsatisfactory teaching performance may lead to a } \\
\text { termination decision. }\end{array}$ & 2.29 & 1.33 & 36.8 & 29.2 & 11.9 & 12.3 & 9.3 \\
\hline $\begin{array}{l}\text { Teachers could be transferred to administrative positions } \\
\text { based on their unsatisfactory performance evaluations }\end{array}$ & 2.44 & 1.23 & 25.8 & 35.8 & 14.5 & 16.7 & 7.2 \\
\hline
\end{tabular}

\subsection{Problems Causing Teachers' Dissatisfaction of Performance Management System}

This section of the questionnaire aimed to address the organisational teachers' dissatisfaction of performance management system that may negatively affect the perfrormance management system in Saudi schools. The summary of responses among teachers was as shown in Table 1.4. The results show that the majority of the teachers have the same opinion on most of the statements. Therefore, it can be said, that these issues are believed to clearly exist and might prevent the effectiveness of the teacher performance management system.

Table 6-10. the responses of Likert-item scale for the problems related to PMS

\begin{tabular}{|c|c|c|c|c|c|c|c|}
\hline \multirow[t]{2}{*}{ Items } & \multirow[t]{2}{*}{ Mean } & \multirow[t]{2}{*}{ SD } & \multicolumn{5}{|c|}{ Percentage } \\
\hline & & & 1 & 2 & 3 & 4 & 5 \\
\hline $\begin{array}{l}\text { There is a lack of awareness of some teachers about the } \\
\text { influence of the performance management process in terms } \\
\text { of developing their performance. }\end{array}$ & 3.75 & 1.32 & 9.3 & 11.9 & 11.3 & 28.6 & 38.6 \\
\hline $\begin{array}{l}\text { The constant surveillance caused by the performance } \\
\text { management process may result in teachers' resistance to } \\
\text { the Performance Management system. }\end{array}$ & 3.67 & 1.31 & 10.5 & 8.5 & 12.1 & 32.1 & 36.6 \\
\hline $\begin{array}{l}\text { Teachers are not involved in setting performance criteria } \\
\text { that are used during the evaluation period. }\end{array}$ & 3.77 & 1.26 & 8.7 & 9.5 & 12.3 & 34.7 & $34 / 7$ \\
\hline $\begin{array}{l}\text { There is poor communication between teachers and head } \\
\text { teachers. }\end{array}$ & 3.67 & 1.34 & 9.7 & 12.0 & 10.6 & 28.3 & 39.4 \\
\hline $\begin{array}{l}\text { There is control by school management over teachers' } \\
\text { achievement of the objectives. }\end{array}$ & 3.72 & 1.25 & 6.6 & 16.3 & 7.4 & 37.6 & 32.1 \\
\hline
\end{tabular}




\begin{tabular}{|c|c|c|c|c|c|c|c|}
\hline $\begin{array}{l}\text { There is a lack of observation of the Performance } \\
\text { management process by top management in the Saudi } \\
\text { Ministry of Education. }\end{array}$ & 3.77 & 1.34 & 11.0 & 9.2 & 11.4 & 28.9 & 39.6 \\
\hline $\begin{array}{l}\text { The social relations between teachers and head teachers may } \\
\text { affect the head teacher's overall evaluation decision. }\end{array}$ & 3.73 & 1.31 & 9.2 & 11.6 & 12.4 & 28.5 & 38.4 \\
\hline $\begin{array}{l}\text { Head teachers are not well prepared and trained to conduct } \\
\text { the performance management process. }\end{array}$ & 4.13 & 1.16 & 5.1 & 6.2 & 12.0 & 23.6 & 53.1 \\
\hline $\begin{array}{l}\text { The head teacher rates teachers either too harshly or too } \\
\text { positively (based on the head teacher' own standards) which } \\
\text { may influence the Performance management process. }\end{array}$ & 3.73 & 1.32 & 9.6 & 11.2 & 12.5 & 27.7 & 39.0 \\
\hline
\end{tabular}

\section{Discussion}

The findings of the study demonstrate that the perceptions of teachers regarding their performance management system are most commonly oriented towards dissatisfaction. The results show that there are problems related to the performance management process. Firistly, It is clear from the findings that there is a general trend among the teachers examined to see a deficiency in the ability of performance management to clarify the Ministry's strategies and objectives. According to Armstrong (2014) without a coherent strategy and clear objectives, an organisation will lack the focus necessary to achieve goals and develop plans that will move the organisation forward. A lack of clear objectives means that the organisation does not have a clear vision for the future; therefore, predetermined objectives will not be employed to develop long-term growth and productivity plans that are essential for the sustained success of the organisation. This finding is supported by the theory of goal-setting, which states that performance goals, objectives and expectations should be clear and understandable so as to motivate employees; otherwise, employees have no clear view of what management expects them to work towards (Locke \& Latham, 2002). Locke and Latham (1990) argued that the reason setting goals and objectives usually has a positive influence on performance is that specific and clear goals influence choice, effort and persistence. In other words, clear goals and objectives increase employees' focus on what is to be achieved instead of putting it off to a later time.

In addtion, it might be possible to state that according to the above results of the respondents, some head teachers did not give teachers feedback on a periodic basis to help teachers to improve their performance. Indeed, the failure to give ongoing feedback defeats the purpose of the performance management process, leaving employees frustrated and demotivated such that they do not take the evaluation seriously (Robert, 2003). Roberson and Stewart (2006) stated that managers who provide honest and accurate feedback were considered more procedurally and informationally fair.

Moreover, the analysis systematically demonstrates that the majority of respondents saw that some issues exist related to the performance appraisal stage in the Saudi public schools. These issues were seen as preventing an accurate performance appraisal from taking place within the schools. Thus, it is obvious from the findings that in general, the majority of teachers surveyed were largely unsatisfied about the performance appraisal stage of the current performance management. The appraisal process follows unclear, poorly balanced procedures that can lead to inaccurate results. According to Lawler (1967) dissatisfaction with evaluations may lead to a decline in motivation and a sense of injustice. The lack of accurate results from the evaluation process make it difficult to link performance to administrative decisions such as promotions, rewards, training and development.

The performance management system for Saudi teachers was found not to capture the necessary information for managers to make informed decisions and policies regarding the teachers; moreover, it can be concluded that there is no link between performance management and the reward and recognition system. Additionally, the findings revealed that teachers are not provided with the necessary training and development that they need in order to improve their performance. It was further revealed that there is no strong relationship between poor performance management results and taking necessary actions to address unsatisfactory performance as management does not take corrective measures in order to help underperforming employees. It can be said that performance managemnt system for Saudi teachers is used more for evaluation than as a tool to aid teacher development. The findings show that the Ministry does not provide development opportunities or rewards to teachers and that the evaluation report used does not address future decisions related to teachers. Consequently, the performance management focuses on past actions more than on future improvement. Additionally, in terms of dismissal and transfer decisions, most of the teachers surveyed believed that individuals are not terminated or transferred based on poor performance results. Teaching in Saudi Arabia is considered a lifelong job; that is, no 
teacher can be dismissed or penalised for poor performance. According to Bartol and Martin (1998) Performance appraisal results can be either positive or negative. In the case of positive results, management should promote the employee, increase their salary, offer financial and non-financial rewards, or a mixture of these. In the case of unsatisfactory performance appraisal results, management should take corrective action immediately, such as a systematic correction and development support to provide assistance for poorly-performing employees. Corrective measures include training, retraining, designing a performance improvement plan, re-setting clear performance standards and providing appropriate facilities in the work environment. This finding is also supported by the expectancy theory (Vroom, 1964), which states that rewards motivate employees to work harder and thus improve performance as promotion and punishment guide human behaviour. Individual performance improves when rewards are closely related to performance. According to Lehman and Geller (2004) states that reward for performance enhances the effort of individuals and thus improves performance.

Furthermore, Furthermore, the findings indicated that some issues related to performance management are believed to clearly exist. Forexample, from the teachers' perspective, issues related to the fairness of evaluation exist and might prevent their effective evaluation. According to the current study's survey findings, most teachers believed that many different kinds of bias can show up during the performance management process that may lead to teachers' resistance to such systems. Such problems might negatively impact the teachers' development, growth, financial rewards and, ultimately, their annual evaluations. In such cases, the teachers feel unfairly treated because the appraisal standards seem unfair and unreasonable. This might lead to despair, mistrust, or hostility between teachers and head teachers during appraisals and to the system failing to differentiate between teachers that perform well and those that perform poorly. In the theory of procedural justice, individuals' perceptions are essential as their reactions to procedures depend on how they perceive these procedures rather than what these procedures actually are (George and Jones, 1999). This theory suggests that individuals will be more motivated to perform when the procedures used to make decisions on the distribution of rewards are fair and when their performance evaluation is accurate. If their performance is not accurately assessed due to personal feelings that affect the evaluation or because the evaluator is not well-versed regarding the employee's contribution to the work, the motivation will, consequently, be reduced, as will individuals' performance.

Additionally, the survey respondents saw teachers as not being involved in the evaluation process and as marginalised by management in terms of the performance management process. Aguinis (2015) emphasised that it is necessary to involve employees in the PM process because it gives them a sense of fairness and a feeling of security regarding this process. Their involvement also increases the employees' commitment to meeting performance objectives. The findings of this study also show that the teachers were not adequately trained in implementing the performance management system, leaving them with little understanding of the system and related procedures. The results therefore show that head teachers did not have adequate skills to carry out the performance management process, therefore, head teachers need to have advance training in order to conduct the performance management process effectively and teachers need to be more aware of the benefits of the performance mangement system. According to Fryer et al (2009) the failure to implement performance management system is usually due to lack of the knowledge, skills, and training required by management and employees. Managers may not be equipped with the skills and training needed to carry out performance planning, supervision, evaluation, evaluation interviews and providing feedback. Employees themselves may lack training on the importance of such systems in improving their performance, how to set objectives and how to prepare for performance review meetings. The management should therefore be responsible for educating employees to improve their attitude towards appraisal by emphasizing its benefits to them, such as developing their skills, identifying their training needs and examining their suitability for pay rises or other rewards.

\section{Conclusion}

This study represents an attempt to fill the gaps in the literature regarding performance management systems in the context of the Saudi Ministry of Education in order to develop the Saudi educational system in general and teachers' performance in particular. Further, its aim is to evaluate the effectiveness of the current performance management system in reflecting the actual performance of Saudi teachers. There is a general dissatisfaction with the performance management systems among teachers. The current performance management systems for teachers is inadequate in accurately judging their performance and meeting their development requirements; hence, the current performance management systems should be re-evaluated. There is a need to review the various issues and challenges related to the implementation of a performance management systems. The current performance management systems for Saudi teachers does not capture the necessary information for managers to make informed decisions and policies regarding the teachers (e.g., rewards, training, and transfers). Moreover, 
the results also indicate that head teachers do not have adequate skills to carry out the performance management process and that certain organisational problems are believed to exist that evoke teachers' resistance to the performance management process.

The outcomes of this research are expected to provide the Ministry of Education with information that would be helpful in improving the management of schools' and teachers' performance. Such improvements are likely to have a significant impact on the quality of education. The findings are also expected to help the Ministry of Education in developing new policies and understanding the impact of these policies on the current system. The results of this study can help school administrators to learn better ways of evaluation to help teachers achieve higher levels of performance. The outcomes of the study can help the teachers to share their opinions about the weaknesses of the performance management system that need improvement to make the performance management system more effective and, hence, more valuable to their work. It can also assist teachers to see how their roles in the organisation contribute to the overall success of the learning process, thereby increasing teachers' morale. Therefore, this study has proposed recommendations to overcome the shortcomings of the existing system and to enhance teachers' satisfaction with their performance management.

\section{Recommendation}

Among the outcomes of this study is a suggestion that it is important to clarify and identify teachers' job roles, responsibilities, and performance criteria, as well as explain how teachers' performance is linked to the Ministry's overall performance. Head teachers and teachers should work out their specific objectives and ways to measure progress towards achieving them. Additionally, ongoing feedback should be provided by head teachers; providing feedback is a vital factor in creating open dialogue between employees and managers and helps identify employees' strengths and weaknesses. As the most important part of a performance management system, performance appraisals should be fair and accurate. Thus, it is important for the decision-makers in the Saudi public schools and the Ministry to consider the performance management outcomes when planning their teacher training and development programmes. The study also recommends that head teachers at Saudi schools should be provided with adequate training on the performance management process. Training courses should also be implemented in order to educate teachers about the importance of the perormance management system in the development of teacher skills. There is a need to involve teachers in the design, development and implementation of a performance management system. Research has shown that the participation of employees in the development of a performance management system and the winning of their commitment to organisational goals and values leads to improved, motivated performance and a high level of employee acceptance of the performance management system.

\section{References}

Aguinis, H. (2015). Performance management (4th ed.). Pearson Prentice Hall.

Armstrong, M. (2014). A handbook of human recourse management practice (13th ed.). Kogan Page.

Atkinson, A., Burgess, S., Croxson, B., Gregg, P., Propper, C., Slater, H., \& Wilson, D. (2009). Evaluating the impact of performance-related pay for teachers in England. Labour Economics, 16(3), 251-261. https://doi.org/10.1016/j.labeco.2008.10.003

Bartol, K. D., \& Martin, D. (1998). Management. McGraw-Hill Co.

Bezuidenhout, M. C. (Ed.). (2000). Managing for healthy labour relations: A practical guide for health services in southern Africa. Van Schaik.

Brower, R., \& Beach, B. (2005). Transformational leadership \& decision making in schools. Corwin Press.

Comrey, A., \& Lee, H. (1992). A first course in factor analysis. Erlbaum.

Darling-Hammond, L., LaPointe, M., Meyerson, D., \& Orr, M. (2007). Preparing school leaders for a changing world: Lessons from exemplary leadership development programs. Stanford Educational Leadership Institute.

Dolton, P. M., \& Arnaud, S. C. (2003). Teacher pay and performance. Institute of Education Publications.

Duflo, E., Hanna, R., \& Ryan, S. P. (2012). Incentive work: Getting teachers to come to school. American Economic Review, 102(4), 1241-1278. https://doi.org/10.1257/aer.102.4.1241

Fryer, K., Antony, J., \& Ogden, S. (2009). Performance management in the public sector. International Journal of Public Sector Management, 22(6), 478-498. https://doi.org/10.1108/09513550910982850

Gentle, D. (2001). Managing performance management in the performing school. In D. Gleeson \& C. Husbands 
(Eds.), The performing school: Managing teaching and learning in a performance culture (pp. 20-32). Routledge Falmer.

Glewwe, P., Llias, N., \& Kremer, M. (2010). Teacher incentives. American Economic Journal: Applied Economics, 2(3), 205-227. https://doi.org/10.1257/app.2.3.205

Heystek, J., Roos, C., \& Middlewood, D. (2005). Human resource management in education. Heinemann Publishers.

Jones, G. R., \& George, J. M. (1999). Understanding and managing organizational behavior (2nd ed.). Wesley Publishing Company.

Kingdon, G. G., \& Teal, F. (2007). Does performance related pay for teachers improve student performance? Some evidence from India. Economics of Education Review, 26(4), 473-486. https://doi.org/10.1016/j.econedurev.2006.02.007

Latham, G. P., \& Locke, E. A. (1979). Goal setting: A motivational technique that works. Organisational Dynamics, 8(2), 442-447. https://doi.org/10.1016/0090-2616(79)90032-9

Latham, G. P., Borgogni, L., \& Petitta, L. (2008). Goal setting and performance management in the public sector. International Public Management Journal, 11(4), 385-403. https://doi.org/10.1080/10967490802491087

Lawler, E. (1967). The multitrait-multirater approach to measuring managerial job performance. Journal of Applied Psychology, 51(5), 369-381. https://doi.org/10.1037/h0025095

Lehman, P. H., \& Geller, E. S. (2004). Behavior analysis and environmental protection: Accomplishments and potential for more. Behavior and Social Issues, 13(1), 13-33. https://doi.org/10.5210/bsi.v13i1.33

Locke, E. A., \& Latham, G. P. (1990). A theory of goal setting \& task performance. Prentice-Hall, Inc.

Locke, E. A., \& Latham, G. P. (2002). Building a practically useful theory of goal-setting and task motivation. American Psychologist, 57(9), 705-717. https://doi.org/10.1037/0003-066X.57.9.705

Locke, E. A., Frederick, E., Lee, C., \& Bobko, P. (1984). Effect of self-efficacy, goals, and task strategies on task performance. Journal of Applied Psychology, 69(2), 241-251. https://doi.org/10.1037/0021-9010.69.2.241

Machingambi, S., (2013) Teachers' perceptions on the implementation of the performance management system in Zimbabwe. International Journal of Educational Sciences, 5(3), 217-225. https://doi.org/10.1080/09751122.2013.11890081

Marsden, S. F. (2000). Why does performance pay de-motivate? Financial incentives versus performance appraisal. Center for Economic Performance.

Muralidharan, K., \& Sundararaman, V. (2009). Teacher performance pay: Experimental evidence from India. National Bureau of Economic Research. https://doi.org/10.3386/w15323

Murnane, R. J., \& Cohen, D. K. (1986). Merit pay and the evaluation problem: Why most merit pay plans fail and a few survive. Harvard Educational Review, 56(1), 1-17. https://doi.org/10.17763/haer.56.1.18q2334243271116

Organisation for Economic Cooperation and Development [OECD] (2005). Teachers matter: Attracting, developing and retaining effective teachers. Thomson Learning.

Roberson, Q. M., \& Stewart, M. M. (2006). Understanding the motivational effects of procedural and informational justice in feedback processes. British Journal of Psychology, 97(3), 281-298. https://doi.org/10.1348/000712605X80146

Robert, G. E. (2003). Employee performance appraisal system participation: A technique that works. Public Personnel Management, 31(1), 333-342. https://doi.org/10.1177/009102600303200105

Robins. S. P. (2007). Organisational behaviour: Global and southern African perspectives. Pearson Education South Africa.

Santiago, P., Roseveare, D., van Amelsvoort, G., Manzi, J., \& Matthews. P, (2009). Teacher evaluation in Portugal. Retrieved from http://www.OECD.org/portugal/43327186.pdf

Sergiovani, T., \& Starrat, R. (1993). Supervision: Human perspectives. McGraw Hall.

Shultz, P. (2006). Psychology and work today: An introduction to industrial and organisational psychology. Pearson Education International. 
Tabachnick, B. G., \& Fidell, L. S. (2001). Using multivariate statistics (4th ed.). Allyn and Bacon.

Thibaut, J., \& Walker, L. (1975). Procedural justice: A psychological analysis. Erlbaum.

Tien, F. F. (2000). To what degree does the desire for promotion motivate faculty to perform research? Testing expectancy theory. Research in Higher Education, 41(6), 723-752. https://doi.org/10.1023/A:1007020721531

Tomlinson, H. (2000). Proposals for performance-related pay for teachers in English schools. School Leadership and Management (Formerly School Organisation), 20(3), 281-298. https://doi.org/10.1080/13632430050128327

Vansteenkiste, M., Zhou, M., Lens, W., \& Soenens, B. (2005). Experiences of autonomy and control among Chinese learners: Vitalizing or immobilizing? Journal of Educational Psychology, 97(3), 468-483. https://doi.org/10.1037/0022-0663.97.3.468

Verspoor, A. (2004). The quest for quality: Towards a learning community. Association for the Development of Education in Africa Newsletter, 16(1), 5-8.

Vroom, V. (1964). Work and motivation. Wiley.

Zikmund, W. G. (2003). Business research methods ( $7^{\text {th }}$ ed.). South-Western Cengage Learning.

\section{Copyrights}

Copyright for this article is retained by the author(s), with first publication rights granted to the journal.

This is an open-access article distributed under the terms and conditions of the Creative Commons Attribution license (http://creativecommons.org/licenses/by/4.0/). 